\title{
More Gender Equality, More Homogamy? A Cohort Comparison in Six European Countries ${ }^{1}$
}

\author{
Julie Falcon* and Dominique Joye**
}

Abstract: We study whether educational homogamy has increased following the rise of women's educational attainment and of egalitarian couples in France, Germany, the Netherlands, Spain, Switzerland and the United Kingdom. From the analysis of data from the European Union and Swiss Labour Force Surveys over a 15-year period (1999-2013), we observe that educational homogamy did not increase across cohorts, although we find substantial differences in the degree of homogamy according to couple arrangements.

Keywords: homogamy, couple arrangements, gender inequality, Europe

\section{Mehr Geschlechtergleichheit, mehr Homogamie? Ein Kohortenvergleich in sechs europäischen Ländern}

Zusammenfassung: Wir untersuchen, ob die Bildungshomogamie in Folge des angestiegenen Bildungsniveaus von Frauen und der Zunahme von egalitären Paaren in Frankreich, Deutschland, der Niederlande, Spanien, der Schweiz und Grossbritannien, zugenommen hat. Basierend auf den Daten der europäischen und schweizerischen Arbeitskräfteerhebungen (1999-2013), konnten wir keine Zunahme der Bildungshomogamie zwischen den Kohorten feststellen. Abhängig von der Paarkonstellation ergaben sich jedoch substantielle Unterschiede im Grad der Bildungshomogamie.

Schlüsselwörter: Homogamie, Paarkonstellationen, Geschlechterungleichheit, Europa

\section{Plus d'égalité de genre, plus d'homogamie ? Comparaison de cohortes dans six pays européens}

Résumé: Nous examinons si l'homogamie de diplôme a augmenté à la suite de l'élévation du niveau d'études des femmes et du nombre de couples égalitaires en France, en Allemagne, aux Pays-Bas, en Espagne et au Royaume-Uni. A partir de l'analyse de données des enquêtes emploi européennes et suisses sur une période de quinze années (1999-2013), nous observons que l'homogamie de diplôme n'a pas augmenté parmi les cohortes, bien qu'il existe des différences substantielles de niveau d'homogamie en fonction des configurations de couple.

Mots clés: homogamie, configurations de couple, inégalités de genre, Europe

* University of Lausanne, Life Course and Inequality Centre (LINES), CH-1015 Lausanne, julie.falcon@unil.ch.

** University of Lausanne, Life Course and Inequality Centre (LINES), CH-1015 Lausanne, dominique.joye@unil.ch.

1 The authors thank the two anonymous reviewers as well as the editors for their helpful comments on previous versions of this article. A preliminary version of this article was presented at the RC28 meeting organized by the National University of Singapore in spring 2016. This publication benefited from the support of the Swiss National Centre of Competence in Research LIVES - Overcoming vulnerability: Life course perspectives, which is financed by the Swiss National Science Foundation (grant number: 51NF40-160590). The authors are grateful to the Swiss National Science Foundation for its financial assistance. 
When it comes to spouse selection, people tend to choose someone of a similar social status to their own (Blossfeld 2009; Blossfeld and Timm 2003; Kalmijn 1998; Schwartz 2013). As Bozon and Héran $(1989,117)$ have underlined, "Cupid's arrows do not strike the social chess-board at random, but form a diagonal line, perfectly visible in the cross-tabulation of social origins of spouses." For social stratification scholars, the study of this phenomenon, known as social homogamy, constitutes a measure of the social closure or openness of a society (Weber 1978). If spouse choice becomes less based on social status, this implies that the crossing of social boundaries is easier and that a society is becoming more open. Partner choice is thus central to understanding the reproduction of social inequality as a whole (Van Bavel 2012,133).

Social homogamy is generally measured by comparing partners' educational attainment or occupational class. We adopt the former measure in this paper. With the recent structural changes, such as educational expansion and the feminization of the labour market, some scholars have maintained that homogamy has increased, especially among egalitarian couples (Blossfeld and Drobnič 2001; Blossfeld and Timm 2003). Alternative views, however, claim that female hypergamy, i. e. the propensity for women to marry upwards, has decreased in favour of female hypogamy, i. e. the propensity for women to marry downwards (Bouchet-Valat 2014). We therefore test these two competing hypotheses by assessing homogamy trends and patterns in six different European nations. The main question we aim to answer is whether homogamy has strengthened and whether this strengthening varies according to couple arrangements. This is an important issue insofar as both scenarios are likely to have very different long-term implications: under the first scenario, a child whose parents are both highly (or less) educated will cumulate (dis)advantages, whereas under the second scenario a child whose parents have different educational levels will have lower risk of accumulating either advantages or disadvantages.

We start by outlining the debates in the literature with respect to homogamy and the incomplete gender revolution. Then, we detail our research methodology before presenting the analysis. Finally, we summarize and discuss our findings.

\section{The incomplete gender revolution: homogamy trends and consequences for couple arrangements}

Over the past century, Western societies have witnessed considerable macro-structural changes. This is particularly true with respect to women's role in society, which has evolved dramatically. Educational expansion has not only increased access to upper secondary and higher education for all (Shavit and Blossfeld 1993; Shavit et 
al. 2007), but has also led to a reversed gender gap in education, given that today more women than men graduate from higher education (Buchmann and DiPrete 2006; DiPrete and Buchmann 2013; Vincent-Lancrin 2008). In the meantime, women's access to the labour market has constantly increased (Oesch 2006). Last but not least, the traditional family model of the "married for life heterosexual couple" has declined as new family forms have emerged (Levy and Widmer 2013; Widmer 2010). However, it remains unclear how these changes have affected homogamy.

According to modernization theory (Blau and Duncan 1967, Kerr et al. 1960; Treiman 1970), the classic theoretical framework in homogamy research, the level of homogamy will vary according to the degree of industrialization and economic development, following an 'inverted U-curve' trend (Smits et al. 1998). First, in the course of the industrialization process, homogamy will increase as education becomes more important in the allocation process and consequently for partner choice. Then, at a late stage of industrialization when the level of economic development is high, homogamy decreases thanks to the rise of romantic love. Thus, following this rationale homogamy should have started to weaken in Western societies from the middle of the $20^{\text {th }}$ century.

Empirical evidence is rather contradictory in this respect. Some country studies have concluded that there has been a decrease in homogamy. This is the case in France (Bouchet-Valat 2014), Great Britain (Halpin and Chan 2003), Norway (Birkelund and Heldal 2003) and Spain (Esteve and Cortina 2006). However, homogamy has increased in some other countries, most notably in Canada and in the US (Hou and Myles 2008; Schwartz and Mare 2005), as well as in Germany (Grave and Schmidt 2012), Ireland (Halpin and Chan 2003) and Switzerland (Joye and Falcon 2016; Levy et al. 1997). Another comparative study of 56 countries concluded that as a consequence of the reversed gender gap in education, female hypogamy has started to exceed female hypergamy (Esteve et al. 2012).

Both theory and empirical research nevertheless have failed to address how homogamy relates to the gendered division of labour within couples. While we have witnessed a tremendous gender equalization trend over the past 50 years, the gender revolution has remained incomplete (Esping-Andersen 2009). On the one hand, the shifting trend in gender relations from the traditional male breadwinner to the dual-earner model has generated greater symmetry between partners among recent generations. On the other hand, some asymmetry persists insofar as the division of labour between men and women within the personal sphere has largely remained unequal, even more so after the transition to parenthood (Le Goff and Levy 2016; Le Goff et al. 2009). Indeed, women still overwhelmingly hold primary responsibility for unpaid work, such as housework and childcare (Blossfeld and Drobnič 2001; Drobnič and Blossfeld 2004). As Blossfeld $(2007,284)$ highlights, "gender role change has been generally asymmetric, with a greater movement of women into the traditional male sphere than vice versa." 
This incomplete gender revolution translates within couples into different forms of arrangements, referred to as multiple equilibrium (Esping-Andersen et al. 2013). Three types of couple arrangements can be distinguished, each describing a different degree of women's prioritization between work and family (Hakim 1996). First, the home-centred lifestyle defines traditional households in which women give priority to family life by focusing on raising children while men play the breadwinner role. Second, the work-centred lifestyle is characteristic of households in which women prioritize their careers. This couple arrangement puts women's careers on an equal footing with those of men and is often associated with childlessness. Third, households with an adaptive lifestyle concern couples who are in between the above configurations. This lifestyle enables women to combine both family and work thanks to their part-time involvement in paid work. Altogether, couple arrangements range from the one - usually male - earner to dual-earners and all the in-between situations of the 1.5 earners.

Couple arrangements tend to vary according to social position and across the life course. For instance, more traditional arrangements tend to be more widespread among both privileged and disadvantaged social classes (Levy et al. 1997). Numerous studies have documented that couple arrangements change after the transition to parenthood in the sense of a strengthening of the traditional division of labour between men and women (Bühlmann et al. 2010; Le Goff and Levy 2016; Le Goff et al. 2009; Widmer et al. 2012). However, couple arrangements probably depend primarily on institutional settings as arrangement choices are made first and foremost according to opportunities and constraints (Krüger and Levy 2001), rather than essentially according to individual preference (Hakim 1996). For instance, European countries display uneven shares of female labour force participation, with Southern European countries reporting lower rates of female labour force participation than Scandinavian or Continental European countries (Esping-Andersen 2009). These differences can be attributed to the diverse obstacles women face in reconciling work and family, which stem from differences in institutional settings.

Following Esping-Andersen's (1990) welfare regime typology and its extension (Ferrera 1996), different institutional settings, each conveying different degrees of gendered life courses, can be isolated. The social-democratic regime, typical of Scandinavian countries, encourages a gender-egalitarian division of labour thanks to state policies promoting dual-earner and dual-carer models. In contrast, under the conservative regime, characteristic of Continental Europe, the traditional gender division of labour is much more marked as policies favour the male breadwinner or 1.5 earner models. Under this regime, interruptions in women's careers and parttime employment are widespread after childbirth. The family-oriented regime, which is emblematic of Southern European countries, has a very traditional division of gender roles. In this regime, women are expected to provide care services to their families and women's labour force participation rate is particularly low. Given that 
reconciling work and family is extremely difficult, women tend to choose between employment and family. Finally, the liberal regime, embedded in Anglo-Saxon countries, provides minimal support to families and relies on the market. As a consequence, female labour force participation tends to be relatively high in order to buy welfare services.

From this standpoint, our research aims to assess whether homogamy has increased over time, whether homogamy affects couple arrangements and whether there are cross-national differences according to the welfare regime. We first build on two competing hypotheses regarding homogamy trends. On the one hand, we could expect homogamy to have decreased in favour of an increase in female hypogamy (H1a). On the other hand, we could expect homogamy to have increased, in particular at the top of the social structure (H1b). We then expect to observe that each type of couple arrangement displays a different degree of homogamy. Although, the causality between homogamy and couple arrangements remains an open question, it is likely that spouse selection constitutes an important predictor of future couple arrangements. Furthermore, insofar as spouse selection and future couple arrangements are likely to be shaped by individuals' gender norms, analysing homogamy and couple arrangements as a configuration, rather than disentangling a strict causal mechanism, will provide insights into the context of the gendered division of labour at the couple level. Increasing gender equality on the labour market and the reversed gender gap in educational attainment are likely to have consequences for homogamy and the division of labour within couples. Because they have invested lots of time and energy in tertiary education, highly educated women tend to become less incline to giving up full time employment, especially after childbirth. As a consequence, to ensure that they can pursue full time employment, these women will be more likely to opt for an egalitarian couple arrangement. To do so, they will be more likely to select a partner with same level of education, or lower. Thus, we hypothesize that egalitarian couples will show higher levels of homogamy among tertiary education graduates and of female hypogamy $(\mathrm{H} 2)$. Last but not least, given that welfare states moderate gender inequality to different extents, the degree of homogamy should vary cross-nationally. The inclination towards gender equality has indeed developed for a far longer time period in social-democratic regime countries than for instance in the conservative regime countries. Therefore, we expect countries to share a common pattern of homogamy but with different degrees of intensity according to their welfare regimes: in gender egalitarian countries homogamy should be relatively high, whereas in gender traditional countries homogamy should be relatively low $(\mathrm{H} 3)$. 
Because we are interested in couple arrangements, i.e. whether couples ${ }^{2}$ are composed of two earners, one earner or 1.5 earners, our analysis focuses on educational homogamy rather than on occupational homogamy. We use the EU Labour Force Survey $^{3}$ and the Swiss Labour Force Survey ${ }^{4}$ over a 15 -year period ${ }^{5}$ (1999-2013) to carry out the analysis. We focus on six countries, namely Switzerland $(\mathrm{CH})$, Germany (DE), Spain (ES), France (FR), the Netherlands (NL) and the United Kingdom (UK). These countries reflect to different extents the conservative (CH, GE, FR, $\mathrm{NL}$ ), family-oriented (ES) and liberal (UK) regimes. We were unfortunately unable to include a country from the social-democratic regime because of the structure of Labour Force Surveys in Scandinavian countries: it is impossible to reconstruct couples as these surveys are drawn on individuals rather than on households.

We focus on couples in which the woman was aged between 30 and 49 years old at the time of the survey. This age range corresponds more or less to the age at which couples are most likely to live with children. Moreover, as the gendered division of labour intensifies after transition to parenthood (Bühlmann et al. 2010; Le Goff and Levy 2016; Le Goff et al. 2009), differences in gender norms according to couple configuration should be the most visible during this life course phase. We also excluded couples in their fifties as the probability of divorce increases with age as a result of a longer exposure to separation risks, but also because divorce risk is likely to diverge between homogamous and heterogamous couples. We then pooled the data and divided them into six birth cohorts, defined according to women's age. Of course, given the structure of our analysis, not all cohorts are analysed at the same age (see Appendix 1). Furthermore, it is worth mentioning that as the age variable in the EU Labour Force Survey is coded in five-year age intervals rather than as a continuous measure, the cohorts we measure are not mutually exclusive: the first cohort is composed of people born between 1950 and 1958 and the second of people born between 1955 and 1963 . The same applies to the four subsequent cohorts. Thus, cohorts' boundaries are a little blurred in that we have a three-year redundancy between each cohort. Despite these limitations, our research design still enables us to draw temporal trends across cohorts because we are working at

2 We make no distinction between married and cohabitating couples and we exclude homosexual couples given the gendered focus of our analysis.

3 This study is based on data from Eurostat, European Union Labour Force Survey microdata, 1999-2013 (CD December 2015). The responsibility for all conclusions drawn from the data lies entirely with the authors.

$4 \quad$ These data were made available by the Swiss Federal Statistical Office.

5 We restrict the analysis to this 15-year period because the EU Labour Force Survey data does not contain a harmonized variable of education before 1998. Furthermore, there was an important reform of the EU Labour Force Surveys in 1998. As a consequence, there are fewer data harmonization issues starting from 1999. 
an aggregated level. The cohort labels are as follows: 1952-1956; 1957-1961; 1962-1966; 1967-1971; 1972-1976; 1977-1981.

To measure educational homogamy, we compare partners' educational attainment. Education is measured using the ISCED 1997 classification (Schneider 2008). We group educational categories into four groups:

1. Lower secondary education or below, corresponding to ISCED 0,1 , and 2.

2. Upper secondary education includes educational programmes, coded in ISCED

3. Post-secondary/tertiary vocational education, composed of ISCED 4 and 5b.

4. Tertiary general education, for all degrees coded in ISCED $5 \mathrm{a}$ and 6.

The ISCED classification provides a harmonized measure of educational levels across countries. It must however be underlined that the comparability of educational levels is never as straightforward as it seems (Schneider et al. 2016). The countries we selected have quite different educational systems, with countries such as the UK having a rather linear system and countries such as Germany, the Netherlands and Switzerland having a dual educational system (i. e. both general and vocational tracks in parallel). This implies that in some countries one educational level can display considerable heterogeneity. As a consequence, the boundaries between some educational levels can be a little blurred in some countries, depending on how authorities classify a given educational title. This is particularly the case for postsecondary education and some tertiary degrees. Nevertheless, given that we could not preform the analysis with a different educational classification with the data used, we are unable to control for this potential measurement problem, inducing probably more imprecision in the measure rather than systematic bias.

Couples that have the same educational attainment are homogamous, whereas those with different educational attainment are heterogamous. Homogamy within the first and the second educational categories is qualified as homogamy at the bottom, whereas homogamy within the third and fourth educational categories is defined as homogamy at the top. We distinguish within heterogamous couples those in which the man has a higher educational level than the woman, described as female hypergamy. In contrast, female hypogamy defines the reverse situation, i. e. where the woman has a higher educational level than the man.

We made a cross-tabulation of couples' employment status to construct a couple arrangements variable (see Appendix 2). Employment status is defined in three categories according to whether individuals are working full time, part time or have no job. We distinguish between (1) symmetrical or 'egalitarian' couples, with the same employment status; (2) partly asymmetrical couples, namely couples whose employment status is slightly dissimilar (for instance full-time/part-time); (3) fully asymmetrical couples, reflecting so called 'traditional couples', where one works full time and the other one has no job. This typology does not fully reflect concepts of dual earners, male breadwinner and 1.5 earners as it contains, for instance, "female 
breadwinner couples" and couples in which the woman works full time and the man part time. However, it has the advantage of not excluding any couple, in particular these "outsider couples." Furthermore, these situations remain the minority and ultimately, symmetrical couples are predominantly composed of dual earners, partly asymmetrical couples of couples in which the man works full time and the women part time and fully asymmetrical couples of couples corresponding to the male breadwinner model (see Appendix 3). Thus, this typology of couple arrangements should reflect quite closely what we want to analyse.

In addition to the calculation of absolute homogamy rates, we applied loglinear models to measure relative homogamy. This modelling technique, widely used in social mobility research, uses the odds ratio statistic to measure the intrinsic association between two or more categorical variables. Applied to the analysis of educational homogamy, this method addresses the problem of the structural differences in the marginal distribution of partners' education. It measures the chances of forming a union with someone with a specific educational level, relative to a person's own educational level. The basic principle of log-linear models is to fit different models to the data, making different assumptions regarding the strength and the pattern of the association between some categorical variables in a contingency table. The main idea is to find the model that provides the closest fit to the data. Then, depending on the assumption made in the model, we can draw conclusions with respect to the strength and pattern of homogamy.

For this research, we fitted log-linear models on a four-way contingency table, cross-classifying birth cohorts (C), couple arrangements (A), men's education (M) and women's education (W). The first model, known as the conditional independence model, assumes that men's and women's educational attainment are independent and is written as follows:

$$
\begin{aligned}
\log \left(m_{i j k l}\right)= & \lambda+\lambda_{i}^{A}+\lambda_{j}^{C}+\lambda_{k}^{M}+\lambda_{l}^{W}+\lambda_{i j}^{A C}+\lambda_{i k}^{A M}+\lambda_{i l}^{A W}+\lambda_{j k}^{C M}+\lambda_{j l}^{C W} \\
& +\lambda_{i j k}^{A C M}+\lambda_{i j l}^{A C W}
\end{aligned}
$$

It assumes that couples are formed totally at random, i.e. regardless of partners' educational attainment. This is the baseline model. The second model is known as the constant association model:

$$
\begin{aligned}
\log \left(m_{i j k l}\right)= & \lambda+\lambda_{i}^{A}+\lambda_{j}^{C}+\lambda_{k}^{M}+\lambda_{l}^{W}+\lambda_{i j}^{A C}+\lambda_{i k}^{A M}+\lambda_{i l}^{A W}+\lambda_{j k}^{C M}+\lambda_{j l}^{C W} \\
& +\lambda_{i j k}^{A C M}+\lambda_{i j l}^{A C W}+\lambda_{k l}^{M W}
\end{aligned}
$$

This posits that there is an association between partners' educational attainment and that this association is constant across cohorts and across couple arrangements. Then, we fitted the uniform difference model - known as the Unidiff model (Erikson and Goldthorpe 1992; Xie 1992). This model assumes that the strength of the 
association between partners' educational attainment varies log-multiplicatively according to a third variable (here respectively cohorts and couple arrangements), while assuming that the homogamy pattern remains stable. Highly parsimonious, this model is able to detect significant difference in terms of trends, at the cost of modelling uniformity in terms of patterns. We tested two combinations of this model, which are written as follows:

$$
\begin{aligned}
\log \left(m_{i j k l}\right)= & \lambda+\lambda_{i}^{A}+\lambda_{j}^{C}+\lambda_{k}^{M}+\lambda_{l}^{W}+\lambda_{i j}^{A C}+\lambda_{i k}^{A M}+\lambda_{i l}^{A W}+\lambda_{j k}^{C M}+\lambda_{j l}^{C W} \\
& +\lambda_{i j k}^{A C M}+\lambda_{i j l}^{A C W}+\beta c \psi o d \\
\log \left(m_{i j k l}\right)= & \lambda+\lambda_{i}^{A}+\lambda_{j}^{C}+\lambda_{k}^{M}+\lambda_{l}^{W}+\lambda_{i j}^{A C}+\lambda_{i k}^{A M}+\lambda_{i l}^{A W}+\lambda_{j k}^{C M}+\lambda_{j l}^{C W} \\
& +\lambda_{i j k}^{A C M}+\lambda_{i j l}^{A C W}+\beta a \psi o d
\end{aligned}
$$

The third model tests whether educational homogamy changes across cohorts and the fourth model whether educational homogamy varies across couple arrangements. In other words, these models assume that educational homogamy increased or decreased across cohorts (model 3 ) and that it is stronger or lower according to couple arrangements (model 4). Inspecting the Unidiff parameters enables us to assess in which direction homogamy varies: if the Unidiff parameters are under/over 1, this implies that homogamy is lower/greater than in the reference category (i.e. 1).

In a last set of models, we also modelled the association pattern of educational homogamy. We fitted three different topological log-linear models, each conveying a different assumption concerning the homogamy pattern. In general terms, these models can be written as follows:

$$
\begin{aligned}
\operatorname{low}\left(m_{i j k l}\right)= & \lambda+\lambda_{i}^{A}+\lambda_{j}^{C}+\lambda_{k}^{M}+\lambda_{l}^{W}+\lambda_{i j}^{A C}+\lambda_{i k}^{A M}+\lambda_{i l}^{A W}+\lambda_{j k}^{C M}+\lambda_{j l}^{C W} \\
& +\lambda_{i j k}^{A C M}+\lambda_{i j l}^{A C W}+\lambda_{a(k l)}^{\text {matrix }}
\end{aligned}
$$

where the term matrix refers to topological matrices fitted to the data (for detail of matrices, see Figure 1). The first matrix is called homogamy. It specifies that the entire association between partners' educational attainment is captured on the main diagonal, but that the homogamy association differs for each educational level. The second topological log-linear model is called crossing and is actually composed of three matrices. It models three different barriers to be crossed between opposite educational categories: (1) a barrier between graduates of lower secondary education or below and graduates of higher levels; (2) a barrier between secondary education graduates and post-secondary/tertiary education graduates; (3) a barrier between tertiary general education and other graduates. The third and last model is the symmetry model. It posits that the educational homogamy pattern is symmetrical between men and women and that each pair of cells of the table has a different degree of association. 
Figure $1 \quad$ Matrix details for topological log-linear models

Homogamy model Crossing model
$\left(\begin{array}{llll}1 & 0 & 0 & 0 \\ 0 & 2 & 0 & 0 \\ 0 & 0 & 3 & 0 \\ 0 & 0 & 0 & 4\end{array}\right) \quad\left(\quad\left(\begin{array}{llll}0 & 1 & 1 & 1 \\ 1 & 0 & 0 & 0 \\ 1 & 0 & 0 & 0 \\ 1 & 0 & 0 & 0\end{array}\right)\left(\begin{array}{llll}0 & 0 & 1 & 1 \\ 0 & 0 & 1 & 1 \\ 1 & 1 & 0 & 0 \\ 1 & 1 & 0 & 0\end{array}\right)\left(\begin{array}{llll}0 & 0 & 0 & 1 \\ 0 & 0 & 0 & 1 \\ 0 & 0 & 0 & 1 \\ 1 & 1 & 1 & 0\end{array}\right) \quad\left(\begin{array}{llll}0 & 1 & 3 & 6 \\ 1 & 0 & 2 & 5 \\ 3 & 2 & 0 & 4 \\ 6 & 5 & 4 & 0\end{array}\right)\right.$

Last but not least, we assess the models' goodness of fit by looking at the BIC statistic (Raftery 1995): the lower the BIC, the more parsimonious the model. This analysis was undertaken using R and LEM software (R Core Team 2016; Vermunt 1997).

\section{$4 \quad$ Analysis}

We first start with some descriptive statistics on country differences in the distribution of educational expansion and couple arrangements. Then, we analyse absolute and relative educational homogamy across cohorts and couple arrangements. We mention which result relates to which hypothesis by indicating the hypothesis label in the text between brackets and discuss thoroughly whether they are corroborated or not in the conclusion.

\subsection{Cross-national differences and structural changes across cohorts}

The educational distribution among couples has evolved considerably across cohorts in all six countries (see Figure in Appendix 4). We observe a decrease in the share of graduates from secondary education or below and an increase in the share of graduates from tertiary education. This trend is widespread in each country, although it happened at different paces and to different extents. The share of tertiary education graduates in the Netherlands and the UK has always ranged across the highest levels, whereas in France and Spain, these shares have increased more sharply for the cohorts born after 1966. Furthermore, we observe that the share of women graduating from tertiary education has outpaced that of men over cohorts in all countries, although this trend is more recent in Germany and Switzerland than in France, Spain and the UK. One last interesting thing worth noting is that graduation shares have converged across countries for men but not for women.

Couple arrangements vary greatly according to country (see Table in Appendix 3). France has the highest share of symmetrical couples (50\%), followed by Spain $(44 \%)$ and the UK (42\%). However, Spain also shows the highest share of fully asymmetrical couples (42\%), making Spain the most "extreme" case out of the six countries studied in terms of couple arrangements. Switzerland also has 
one of the highest shares of fully asymmetrical couples (35\%). Partly asymmetrical couples are the most widespread in the Netherlands (62\%), followed by Switzerland (42\%), Germany (39\%) and the UK (38\%).

If we had to make a ranking of the six countries from the most traditional to least traditional, it would probably be organized as follows: Spain, the Netherlands, Switzerland, Germany, the UK and France. Of course, these countries' variations reflect national specificities. For instance, in Germany, the Netherlands and Switzerland, it is possible to live comfortably on 1.5 incomes, whereas this is less the case in France and the UK. Furthermore, in Spain it is particularly difficult to reconcile work and family life, which explains why we observe this high share of fully asymmetrical couples. However, trends across cohorts in couple arrangements show that the share of fully asymmetrical couples has decreased in Spain, while shares of partly asymmetrical and symmetrical couples have increased. This means that couple arrangements in Spain have been moving away from the traditional male breadwinner model over recent decades. In the other countries, however, couple arrangements have remained stable insofar as no major trend across cohorts is revealed.

\subsection{Absolute educational homogamy trends}

We depict absolute educational homogamy rates in Figure 2 for the first and the last birth cohorts in the six countries and according to couple arrangements. We first of all observe that educational homogamy at the top has increased and educational homogamy at the bottom has decreased $(\mathrm{H} 1 \mathrm{~b})$. These trends are widespread in each country, although homogamy at the bottom still predominates over homogamy at the top - the gap between both has decreased. When we look at differences according to couple arrangements, we see that these evolutions touch all couple configurations. In this regard, structural changes have not been diffused only in one couple configuration in particular. We nevertheless see that symmetrical couples display higher levels of homogamy at the top and asymmetrical couples higher levels of homogamy at the bottom $(\mathrm{H} 2)$. What is also noteworthy is that cross-national differences in the homogamy rate are actually quite low (H3): for all countries, homogamy at the top accounts for about 20\% and homogamy at the bottom for about 30\% in the youngest cohort. When put together (see Figure in Appendix 5), homogamy rates display a very high stability over cohorts $(\mathrm{H} 1 \mathrm{a} / \mathrm{H} 1 \mathrm{~b})$. Only in Spain do homogamy rates decrease considerably across cohorts (from $71 \%$ to $49 \%$ ) to converge with those of other countries.

From the investigation of heterogamy trends (see second part of Figure 2), we see that female hypergamy across cohorts has decreased while female hypogamy has increased (H1a). Female hypogamy has even become the norm as in the most recent cohort there is more female hypogamy than female hypergamy. Thus, women now "dominate" in heterogamous couples - in educational terms at least. Again, this trend is not characteristic of one particular couple configuration; it affects the entire 

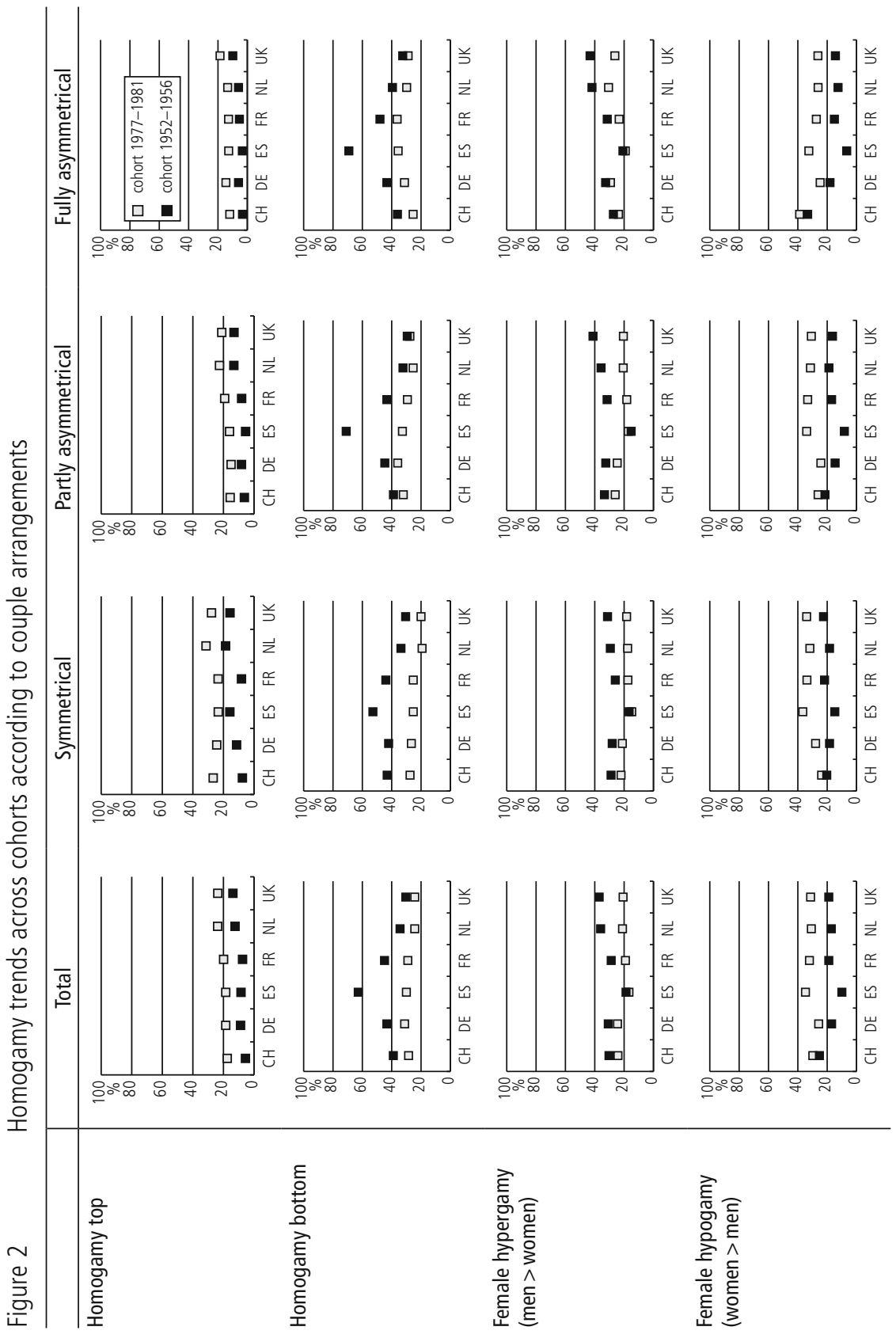
population. We nevertheless observe some small differences in the representation of female hyper- and hypogamy according to couple configuration (H2). Indeed, fully asymmetrical couples exhibit slightly higher rates of female hypergamy and asymmetrical couples slightly lower rates of female hypogamy. These trends are true for all countries, with the exception of Switzerland where fully asymmetrical couples display higher levels of female hypogamy.

Altogether, we observe that more equal - or symmetrical - couples are more widespread among couples in which both have tertiary education or the woman has a higher educational level than the man $(\mathrm{H} 2)$, although this trend is not systematic, as the Swiss case shows. However, we further notice that structural changes, namely increased homogamy at the top and increased female hypogamy, affect all types of couple arrangements. Does the analysis of relative homogamy reveal similar trends?

\subsection{Relative homogamy}

We first analyse whether homogamy has increased across cohorts in relative terms. Then we look at whether couple arrangements display different degrees of homogamy. Finally, we assess the shape of the homogamy pattern by fitting a set of topological log-linear models to the data. The models fitted are displayed in Table 1 .

Trends across cohorts (assessment of $\mathrm{H} 1 \mathrm{a} / \mathrm{H} 1 \mathrm{~b} / \mathrm{H} 3$ ). In countries such as Germany, Spain and the Netherlands, the Unidiff model (M3) adjusts better to the data than does the constant association model (M2). Thus, it seems that in these countries there has been some change in the degree of homogamy over cohorts. In contrast, in France, the UK and Switzerland, the constant association model has to be preferred. Nevertheless, when looking at the Unidiff parameters, which are displayed in the left panel of Figure 3, we observe that in most countries homogamy has remained relatively stable. At best, it has slightly decreased across cohorts rather than increased, although these trends tend to not be large. For the Netherlands, however, we observe in the last cohort a strong decreasing homogamy trend. At this stage, we are unable to conclude whether this trend will last over time or whether this is, for instance, an age effect. Of all countries, Germany is a special case. This is the only country where educational homogamy has increased across cohorts. This trend is particularly sharp.

Trends across couple arrangements (assessment of $\mathrm{H} 2 / \mathrm{H} 3$ ). We notice for all countries but one that couple arrangements show different degrees of homogamy, given that the Unidiff model (M4) must be preferred quasi systematically to the constant association model (M2). As can be seen from the right panel in Figure 3, which displays corresponding Unidiff parameters for partly and fully asymmetrical couples compared to symmetrical couples, in the UK there is hardly any difference in couple arrangements' degree of educational homogamy. In contrast, in all other countries, asymmetrical couples show lower levels of homogamy compared to symmetrical couples. This implies that homogamy is higher within egalitarian couples. 
Table $1 \quad$ Log-linear models fitted to the data

\begin{tabular}{|c|c|c|c|c|c|c|c|c|c|c|c|c|c|c|}
\hline & & \multirow[t]{2}{*}{$d f$} & \multicolumn{2}{|c|}{$\begin{array}{c}\mathrm{CH} \\
(\mathrm{N}=231333)\end{array}$} & \multicolumn{2}{|c|}{$\begin{array}{c}D E \\
(N=529961)\end{array}$} & \multicolumn{2}{|c|}{$\begin{array}{c}E S \\
(N=416454)\end{array}$} & \multicolumn{2}{|c|}{$\begin{array}{c}F R \\
(N=1255161)\end{array}$} & \multicolumn{2}{|c|}{$\begin{array}{c}N L \\
(N=374541)\end{array}$} & \multicolumn{2}{|c|}{$\begin{array}{c}\text { UK } \\
(\mathrm{N}=179514)\end{array}$} \\
\hline & & & L2 & $\mathrm{BIC}$ & L2 & $\mathrm{BIC}$ & L2 & $\mathrm{BIC}$ & L2 & $\mathrm{BIC}$ & L2 & $\mathrm{BIC}$ & L2 & $\mathrm{BIC}$ \\
\hline $\mathrm{M} 1$ & $\begin{array}{l}\text { Conditional } \\
\text { independ- } \\
\text { ence }\end{array}$ & 162 & 51220 & 49219 & 112293 & 110157 & 140179 & 138083 & 388428 & 386153 & 79626 & 77547 & 45689 & 43729 \\
\hline M2 & $\begin{array}{l}\text { Constant } \\
\text { association }\end{array}$ & 153 & 4408 & 2519 & 2394 & 377 & 1250 & -730 & 4458 & 2309 & 1232 & -732 & 482 & -1369 \\
\hline M3 & $\begin{array}{l}\text { Unidiff } \\
\text { cohort }\end{array}$ & 148 & 4375 & 2547 & 2092 & 141 & 1171 & -744 & 4354 & 2276 & 1073 & -826 & 467 & -1324 \\
\hline M4 & $\begin{array}{l}\text { Unidiff } \\
\text { couple } \\
\text { arrange- } \\
\text { ment }\end{array}$ & 151 & 3703 & 1838 & 1369 & -621 & 1065 & -889 & 3909 & 1789 & 1109 & -828 & 480 & -1347 \\
\hline M5a & Homogamy & 158 & 12634 & 10682 & 13490 & 11408 & 7574 & 5530 & 90813 & 88594 & 7619 & 5591 & 6507 & 4595 \\
\hline M5b & Crossing & 159 & 11326 & 9363 & 4232 & 2136 & 5264 & 3207 & 11137 & 8903 & 6289 & 4249 & 1848 & -76 \\
\hline M5c & Symmetry & 156 & 10533 & 8607 & 4146 & 2090 & 1528 & -490 & 4752 & 2562 & 1451 & -551 & 714 & -1173 \\
\hline M6 & $\begin{array}{l}\text { M5a+ } \\
\text { M5c x } \\
\text { couple } \\
\text { arrange- } \\
\text { ment }\end{array}$ & 132 & 7225 & 5446 & 2837 & 939 & 1277 & -586 & 3622 & 1600 & 1085 & -763 & 582 & -1161 \\
\hline
\end{tabular}

Figure $3 \quad$ Parameters for Unidiff log-linear models across cohorts

(M3, left panel) and across couple arrangements (M4, right panel)

Change across cohorts

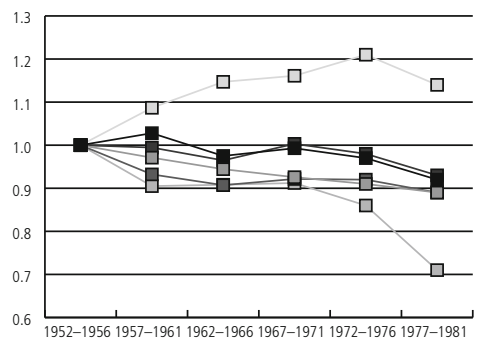

Variation across couple arrangements

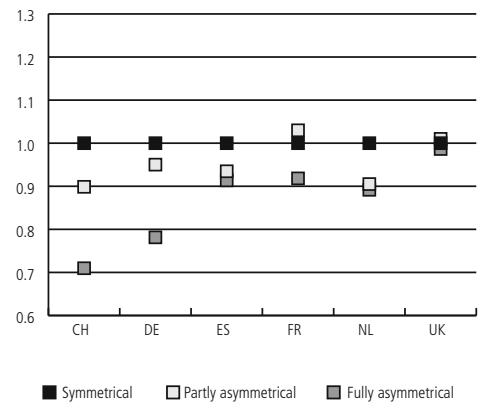

Note: Symmetrical couples are the reference category (i.e. 1) for the graph on the right panel.

The gap between symmetrical and fully asymmetrical couples is particularly great in Germany and Switzerland. These countries are known for being particularly gender traditional; thus, differences in couples might be more extreme in these countries. In France, Spain and the Netherlands, homogamy differences are relatively lower. 
Finally, it is worth noting that in France partly asymmetrical couples display slightly higher levels of educational homogamy than symmetrical couples.

Homogamy patterns (assessment of $\mathrm{H} 1 \mathrm{a} / \mathrm{H} 1 \mathrm{~b} / \mathrm{H} 2 / \mathrm{H} 3$ ). For all countries, the homogamy pattern is characterized by symmetry (M5c), rather than by essentially homogamy on the main diagonal (M5a) or by the crossing of some educational barriers (M5b). This means that the observed increase in female hypogamy is primarily driven by structural changes, while in relative terms spouse selection remains equally similar irrespective of whether this is the man or the woman who has the highest level of education. We further put in a last model (M6) the diagonal model (M5a) together with the symmetry model (M5c) and allow parameters to vary according to couple arrangements, to see whether the homogamy pattern differs with couple configuration. For all countries, with the exception of the UK, we find that this model makes a significant improvement. This implies that the homogamy pattern tends to vary according to couple arrangement. From Figure 4, which displays the corresponding parameters of the homogamy pattern, we observe that overall homogamy dominates over heterogamy, as all homogamy parameters are positive whereas most heterogamy parameters are negative. Homogamy tends to be stronger among graduates of lower secondary education or below (E1-E1) and of tertiary general education (E4-E4). When it comes to heterogamy, it is less unlikely between close educational levels, for instance between graduates of lower secondary education or below and upper secondary education (E1-E2). In contrast, it is much more unlikely between graduates of lower secondary education or below and tertiary education graduates, particularly from the general track (E1-E3 and E1-E4). Nevertheless, these general trends show variation according to couple arrangement to some degree. Homogamy tends to be higher among symmetrical couples and lower among fully asymmetrical couples that have graduated from lower secondary education or below (E1-E1). It is also higher among symmetrical couples with post-secondary/tertiary vocational education (E3-E3) in the Netherlands and Switzerland. Interestingly, in the Netherlands and Spain, we also observe that homogamy among tertiary general education graduates (E4-E4) is more widespread within fully asymmetrical couples. Thus, homogamy at the top in these countries fosters a gender traditional division of labour within couples. In all other cases, no important difference in the degree of homogamy according to couple arrangements is uncovered. With respect to heterogamous configurations, we mostly observe some sharp differences in terms of couple arrangements between extreme educational categories (E1-E3 and E1-E4) in Germany and Switzerland: in these cases, heterogamy is more likely among fully asymmetrical couples and more unlikely among symmetrical couples. Overall, heterogamy tends to be more common among fully asymmetrical couples. All in all, we observe a great degree of commonality in relative homogamy between the six countries studied: (1) a generally constant homogamy trend across cohorts; (2) a higher degree of homogamy among egalitarian couples, especially at the bot- 
Figure 4 Homogamy pattern according to couple arrangements (parameters for model M6)
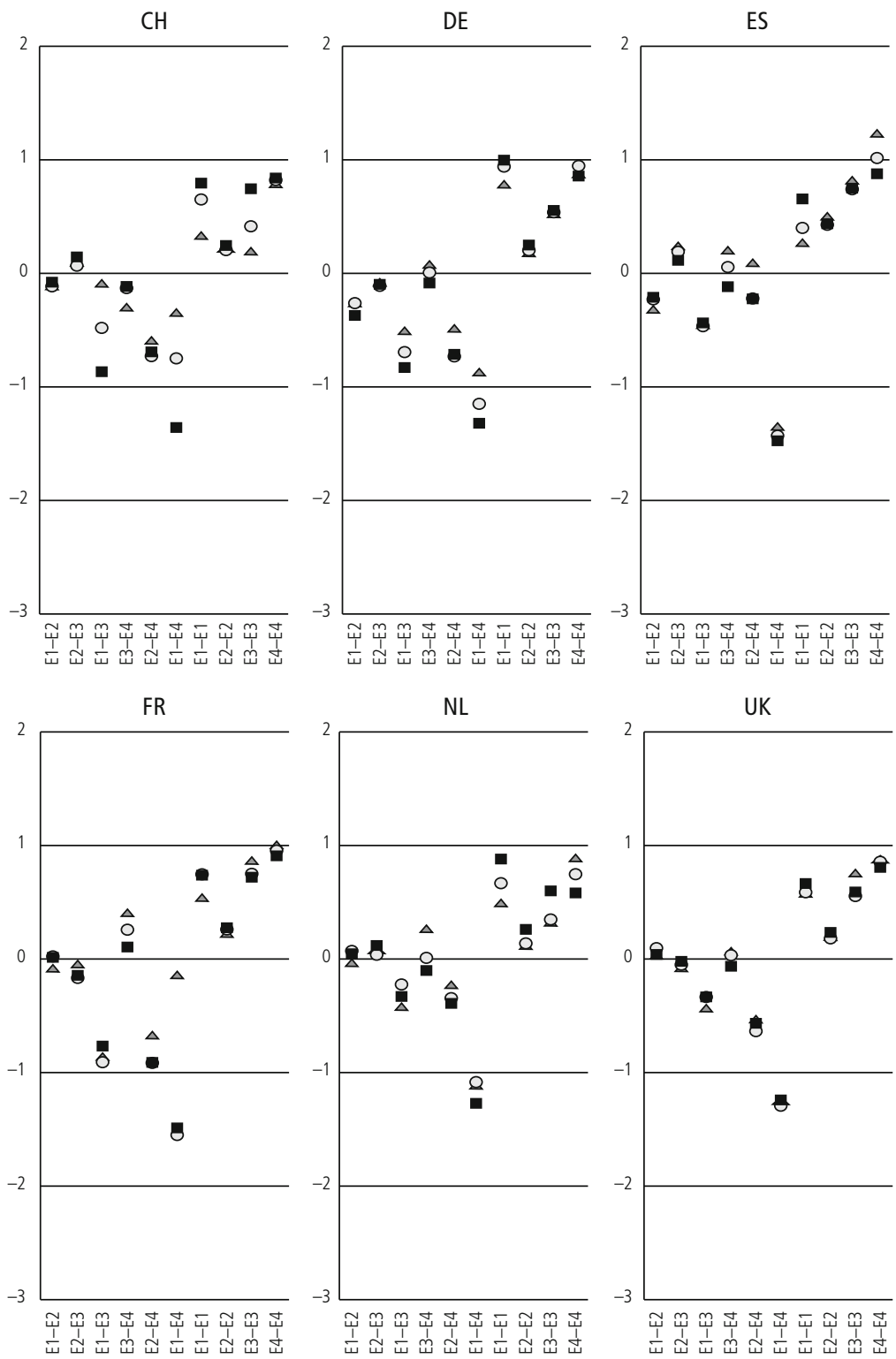

- Symmetrical O Partly asymmetrical $\Delta$ Fully asymmetrical 
tom (E1-E1); (3) an overall homogamy pattern which is symmetrical (i. e. equally similar irrespective of whether it is the man or the woman who has the highest level of education).

\section{Discussion and conclusion}

When it comes to the issue of gender equality within couples, different aspects can be considered: equality in terms of education, through homogamy, but also equality in the way in which partners engage in the job market. This research aimed to assess trends and variations in both domains - educational homogamy and couple arrangements - over time in six European countries, namely France, Germany, the Netherlands, Spain, Switzerland and the UK. With this approach, we look beyond the classic analysis of educational homogamy by analysing how this phenomenon relates to the gendered division of labour within couples. Addressing this issue is relevant in the context of macro-structural changes that Western societies have witnessed over the past century, in particular when it comes to gender relations. Not only has an increasing share of women become active in the labour market, but also the likelihood of graduating from higher education has become higher for women compared to men (DiPrete and Buchmann 2013; Oesch 2006).

The analysis of homogamy together with the various couple arrangements sheds light on the paradoxical consequences of an increase in homogamy for inequality. On the one hand, at the macro level, this implies that social barriers become more difficult to cross and that social fluidity potentially decreases. On the other hand, at the couple level, this likely generates more equality between partners. There is thus a tension between the vertical and horizontal dimensions of inequality, which we highlight in this article.

We tested two competing hypotheses with regard to trends over time in educational homogamy: either a decrease in educational homogamy in favour of an increase in female hypogamy ( $\mathrm{H1a}$ ), or an increase in educational homogamy, in particular at the top of the social structure (H1b). Furthermore, we hypothesized that the degree of educational homogamy would vary according to couple arrangements: egalitarian couples would show a higher degree of homogamy at the top of the social structure and of female hypogamy as women in these couples are likely to be highly educated (H2). Finally, we expected some cross-national variations, with higher levels of educational homogamy in more gender egalitarian countries and lower levels of educational homogamy in more gender traditional countries (H3). To test these hypotheses, we analysed absolute and relative educational homogamy using the EU and the Swiss Labour Force Surveys data over the period 1999-2013.

Through a cohort analysis, we show that educational homogamy has mostly remained stable over time, both in absolute and relative terms, in spite of the fact 
that the share of women graduating from tertiary education outpaced men's share across cohorts in all six countries. In absolute terms, we observe a great stability in shares of homogamous couples, which represent about $50 \%$ of couples. We nevertheless observe changes in the composition of homogamy. Across cohorts, homogamy between tertiary education graduates has increased, whereas homogamy between graduates of lower educational levels has decreased. In the 1977-1981 birth cohort, these shares represent $20 \%$ and $30 \%$ respectively. We also observe that female hypergamy, i. e. the propensity for women to marry upwards, decreased in favour of female hypogamy, i. e. the propensity for women to marry downwards. Thus, in the most recent cohort, women are more likely to have a higher level of education than their partners. This rise in female hypogamy is nevertheless essentially driven by structural changes. Indeed, the analysis of relative homogamy reveals that the homogamy pattern in all six countries is essentially symmetrical. This means that heterogamy does not depend on the partner's gender: in relative terms, spouse selection based on educational attainment is essentially identical for men and women, regardless of whether it is the man or the woman who has a higher level of education.

We also find that educational homogamy displays a high degree of stability across cohorts in relative terms: at best, educational homogamy has tended to decrease slightly rather than increase, although these trends are not statistically significant in most countries. However, two exceptions must be underlined: (1) the Netherlands shows a decrease in educational homogamy in the last cohort and (2) Germany displays a marked increasing educational homogamy trend across cohorts. While this last finding may seem puzzling as we do not see why Germany should be a special case, especially in comparison to similar countries such as the Netherlands and Switzerland, this finding is actually in line with previous research (Grave and Schmidt 2012). An alternative explanation for the deviations of the Netherlands and Germany from other countries could also be found in the way educational attainment is measured in these countries through the ISCED classification (Schröder and Ganzeboom 2014). We are nevertheless unable to test this possible bias at this point.

From this standpoint, our first competing hypotheses ( $\mathrm{H} 1 \mathrm{a}$ and $\mathrm{H} 1 \mathrm{~b})$ are neither totally accepted nor rejected. While we find neither a decrease nor an increase in educational homogamy across cohorts, we find an increase in female hypogamy and in homogamy at the top of the social structure in absolute terms. Yet these compositional changes in observed educational homogamy have been essentially driven by structural changes, as the analysis of relative trends shows.

Our analysis reveals some heterogeneity in the educational homogamy pattern according to couple arrangements in both absolute and relative terms. We defined three sets of couple arrangement (Esping-Andersen et al. 2013; Hakim 1996): (1) symmetrical couples, corresponding to a work-centred lifestyle for women, where usually both partners are in full-time employment; (2) partly asymmetrical couples, corresponding to an adaptative lifestyle for women, where usually the man works 
full-time and the woman part-time; (3) fully asymmetrical couples, corresponding to a home-centred lifestyle for women, where usually the man works full-time and the women does not work. In absolute terms, we observe that symmetrical couples show slightly higher levels of homogamy within tertiary education graduates, whereas asymmetrical couples display higher levels of homogamy within graduates of lower education levels. Furthermore, female hypergamy tends to be slightly more common among fully asymmetrical couples and female hypogamy less common within asymmetrical couples. Regarding differences in relative terms, symmetrical couples tend to exhibit higher levels of homogamy in all countries and asymmetrical couples lower levels of homogamy. Interestingly, further statistical modelling reveals that homogamy is more pronounced among symmetrical couples that have graduated from lower secondary education or below compared to fully asymmetrical couples, whereas no sharp difference in the degree of homogamy according to couple arrangements is observed among couples with tertiary education. We also find that heterogamy is less unlikely among fully asymmetrical couples.

These findings led us to partly reject assumptions made in the second hypothesis (H2), which stated that egalitarian couples would display higher levels of homogamy among tertiary education graduates and of female hypogamy. First, with regard to female hyper- and hypogamy according to couple arrangements, we do not observe strong differences. Second, apparently contradictory findings are uncovered when it comes to homogamy. While in absolute terms egalitarian couples do indeed display higher levels of homogamy when both partners have tertiary education, in relative terms homogamous couples that graduated from lower secondary education or below are more likely to be in an egalitarian couple arrangement than a traditional one. In other words, while it is true that homogamy at the top is more widespread among egalitarian couples, net of structural changes couples that are homogamous at the bottom are more likely to participate equally in the labour market, rather than unequally. In contrast, when it comes to homogamy at the top in relative terms, no big difference according to types of couple arrangements is uncovered. These findings illustrate that the most disadvantaged couples do not face the same opportunities and constraints when it comes to couple arrangement choice as other couples.

Finally, our last hypothesis (H3) is partly rejected, as we do not find strong and systematic cross-national differences in educational homogamy between the most and the less gender egalitarian countries. In all countries, homogamy rates amount to about $50 \%$, with the exception of Spain where we observe a converging trend over time: homogamy rates decreased from $70 \%$ to $50 \%$ across cohorts. Nor do we find strong cross-national differences in relative educational homogamy trends over time. However, some differences arise in terms of homogamy according to couple arrangements. In Germany and Switzerland, asymmetrical couples display lower levels of homogamy. It is in these two countries that heterogamy at the extremes displays the greatest difference in terms of couple arrangements (less likely within 
egalitarian couples and more likely within traditional couples). By contrast, in the Netherlands and Spain, we observe that homogamy among tertiary general education graduates is higher among traditional couple configurations, whereas in France and the UK levels of homogamy are relatively similar regardless of couple arrangements. Thus, it seems that in gender traditional countries, there are more differences in homogamy levels between the different couple configurations than in more gender egalitarian countries.

To summarize, while there have been important changes in women's roles in European societies over the past decades, these changes have not fostered educational homogamy. Overall, we find that both in absolute and relative terms educational homogamy rates display a high degree of stability. Yet, when looking in greater detail, we do find an increase in homogamy between highly educated individuals. Furthermore, although this trend is widespread among all couple configurations, it is more pronounced among egalitarian couples. However, the analysis of relative homogamy reveals that, while homogamy is more likely among egalitarian couples, homogamous couples with low levels of education are more likely to be in an egalitarian rather than in a traditional couple configuration. In contrast, for homogamous couples with higher levels of education, little difference in terms of couple arrangement is uncovered. Last but not least, we find little evidence of cross-national differences in homogamy trends, even though we observe that in the Netherlands and Spain homogamous couples with tertiary general education are more likely to be in a traditional couple configuration, and that in Germany and Switzerland variations in homogamy patterns according to couple arrangements are higher than in other countries. It remains unclear whether these trends relate to welfare regime differences or to the differential timing of the diffusion of gender equality between countries.

We thus arrive at quite challenging conclusions: while gender equality has increased overall in terms of couple arrangements, the degree of educational homogamy has not increased but rather remained constant. This implies that horizontal inequality between men and women has decreased at the couple level, whereas vertical inequality in terms of social barriers has been maintained at the macro level. These findings seem to indicate that the increase in gender equality has created a restructuring of educational homogamy rather than a growth in educational homogamy. Our analysis also underlines that the type of homogamy seems to have an influence on couple arrangement possibilities: the most disadvantaged couples in terms of educational attainment have fewer possibilities than other couples, because of the constraints they face, presumably in terms of labour market opportunities and economic resources. Better-off couples have, on the contrary, more couple arrangement leeway and thus are 'freer' to decide for which arrangement to opt for. This 'choice' dimension is something that has been neglected by the homogamy literature so far. Thus, future research will have to address this aspect, potentially 
by mobilizing the intersectionality research framework, as well as by analysing how these couple arrangements develop over the life course. Country differences should also be analysed in the light of the availability of childcare facilities, which is likely to affect couple arrangements, but also potentially homogamy in the first place.

It is nevertheless important to stress that gender inequality constitutes only one aspect of the system of inequality. Paradoxically, a decrease in horizontal inequality (i.e. here gender inequality) can also imply a reinforcement of vertical inequality (i. e. here class inequality). This is one more argument for a systemic discussion of inequality and social differentiation in contemporary Europe to fully address issues of social justice.

\section{References}

Birkelund, Gunn Elisabeth and Johan Heldal. 2003. Who Marries Whom? Educational Homogamy in Norway. Demographic Research 8(1): 1-30.

Blau, Peter and Otis Duncan. 1967. The American Occupational Structure. New York: Wiley.

Blossfeld, Hans-Peter. 2009. Educational Assortative Marriage in Comparative Perspective. Annual Review of Sociology 35(1): 513-530.

Blossfeld, Hans-Peter. 2007. Linked Lives in Modern Societies. The Impact on Social Inequality of Increasing Educational Homogamy and the Shift Towards Dual-Earner Couples. pp. 275-291 in From Origin to Destination. Trends and Mechanisms in Social Stratification Research, edited by Stefani Scherer, Reinhard Pollak, Gunnar Otte, and Markus Gangl. Chicago: The University of Chicago Press.

Blossfeld, Hans-Peter and Sonja Drobnič. 2001. Careers of Couples in Contemporary Societies: From Male Breadwinner to Dual Earner Families. Oxford: Oxford University Press.

Blossfeld, Hans-Peter and Andreas Timm. 2003. Who Marries Whom? Educational Systems as Marriage Markets in Modern Societies. Dordrecht: Kluwer Academic Publishers.

Bouchet-Valat, Milan. 2014. Les évolutions de l'homogamie de diplôme, de classe et d'origine sociales en France (1969-2011): ouverture d'ensemble, repli des élites. Revue française de sociologie 55(3): 459-505.

Bozon, Michel and Francois Héran. 1989. Finding a Spouse: A Survey of How French Couples Meet. Population: An English Selection 44(1): 91-121.

Buchmann, Claudia and Thomas A. DiPrete. 2006. The Growing Female Advantage in College Completion: The Role of Family Background and Academic Achievement. American Sociological Review 71(4): 515-541.

Bühlmann, Felix, Guy Elcheroth, and Manuel Tettamanti. 2010. The Division of Labour Among European Couples: The Effects of Life Course and Welfare Policy on Value-Practice Configurations. European Sociological Review 26(1):49-66.

DiPrete, Thomas A. and Claudia Buchmann. 2013. The Rise of Women: The Growing Gender Gap in Education and What It Means for American Schools. New York: Russell Sage Foundation.

Drobnič, Sonja and Hans-Peter Blossfeld. 2004. Career Patterns Over the Life Course: Gender, Class, and Linked Lives. Research in Social Stratification and Mobility 21(1): 139-164.

Erikson, Robert and John H. Goldthorpe. 1992. The Constant Flux: A Study of Class Mobility in Industrial Societies. Oxford: Clarendon Press. 
Esping-Andersen, Gøsta. 2009. Incomplete Revolution: Adapting Welfare States to Women's New Roles. Cambridge: Polity.

Esping-Andersen, Gøsta. 1990. The Three Worlds of Welfare Capitalism. Princeton: Princeton University Press.

Esping-Andersen, Gøsta, Diederik Boertien, Jens Bonke, and Pablo Gracia. 2013. Couple Specialization in Multiple Equilibria. European Sociological Review 29(6):1280-1294.

Esteve, Albert and Clara Cortina. 2006. Changes in Educational Assortative Mating in Contemporary Spain. Demographic Research 14(17): 405-428.

Esteve, Albert, Joan García-Román, and Ińaki Permanyer. 2012. The Gender-Gap Reversal in Education and Its Effect on Union Formation: The End of Hypergamy? Population and Development Review 38(3):535-546.

Ferrera, Maurizio. 1996. The "Southern Model" of Welfare in Social Europe. Journal of European Social Policy 6(1): 17-37.

Grave, Barbara S. and Christoph M. Schmidt. 2012. The Dynamics of Assortative Mating in Germany. Rochester, NY: Social Science Research Network, http://papers.ssrn.com/abstract $=2122485$ (15.06.2016).

Halpin, Brendan and Tak Wing Chan. 2003. Educational Homogamy in Ireland and Britain: Trends and Patterns. The British Journal of Sociology 54(4): 473-495.

Hou, Feng and John Myles. 2008. The Changing Role of Education in the Marriage Market: Assortative Marriage in Canada and the United States Since the 1970s. Canadian Journal of Sociology/Cahiers canadiens de sociologie 33(2): 337-366.

Joye, Dominique and Julie Falcon. 2016. Soziale Ungleichheiten in der Schweiz: Eine Bestandsaufnahme und aktuelle Herausforderungen. Pp. 21-41 in Ungleichheit(en) und Demokratie, edited by Béatrice Ziegler. Zurich: Schulthess.

Kalmijn, Matthijs. 1998. Intermarriage and Homogamy: Causes, Patterns, Trends. Annual Review of Sociology 24(1): 395-421.

Kerr, Clark, John Dunlop, Frederick Harbison, and Charles Myers. 1960. Industrialism and Industrial Man. Cambridge: Harvard University Press.

Krüger, Helga and René Levy. 2001. Linking Life Courses, Work, and the Family: Theorizing a Not So Visible Nexus Between Women and Men. Canadian Journal of Sociology 26(1): 145-166.

Le Goff, Jean-Marie and René Levy. 2016. Devenir Parents, Devenir Inégaux. Transition À La Parentalité et Inégalités de Genre. Zurich: Seismo.

Le Goff, Jean-Marie, René Levy, Marlène Sapin, and Martin Camenisch. 2009. Devenir Parent: Changer de Vie. Pp. 211-232 in Transitions dans les parcours de vie et construction des inégalités, edited by Michel Oris, Eric Widmer, Anik de Ribaupierre, Dominique Joye, Dario Spini, Gisela LabouvieVief, and Jean-Marc Falter. Lausanne: Presses polytechniques et universitaires romandes.

Levy, René and Eric Widmer (eds.). 2013. Gendered Life Courses Between Standardization and Individualization: A European Approach Applied to Switzerland. Münster: LIT Verlag.

Levy, René, Dominique Joye, Olivier Guye, and Vincent Kaufmann. 1997. Tous Égaux? De La Stratification Aux Représentations. Zurich: Seismo.

Oesch, Daniel. 2006. Redrawing the Class Map: Stratification and Institutions in Britain, Germany, Sweden and Switzerland. Basingstoke: Palgrave Macmillan.

R Core Team. 2016. R: A Language and Environment for Statistical Computing. R Foundation for Statistical Computing, Vienna, Austria, https://www.R-project.org/ (30.06.2016).

Raftery, Adrian E. 1995. Bayesian Model Selection in Social Research. Sociological Methodology 25: 111-163. 
Schneider, Silke L. 2008. The International Standard Classificaion of Education (ISCED-97). An Evaluation of Content and Criterion Validity for 15 European Countries. Mannheimer Zentrum für Europäische Sozialforschung. Mannheim: Universität Mannheim.

Schneider, Silke L., Dominique Joye, and Christof Wolf. 2016. When Translation Is Not Enough: Background Variables in Comparative Surveys. Pp. 288-307 in The SAGE Handbook of Survey Methodology, edited by Christof Wolf, Dominique Joye, Tom W. Smith, and Yang-chih Fu. London: Sage.

Schröder, Heike and Harry B. G. Ganzeboom. 2014. Measuring and Modelling Level of Education in European Societies. European Sociological Review 30(1): 119-136.

Schwartz, Christine R. 2013. Trends and Variation in Assortative Mating: Causes and Consequences. Annual Review of Sociology 39(1): 451-470.

Schwartz, Christine R. and Robert D. Mare. 2005. Trends in Educational Assortative Marriage From 1940 to 2003. Demography 42(4): 621-646.

Shavit, Yossi and Hans-Peter Blossfeld. 1993. Persistent Inequality: Changing Educational Attainment in Thirteen Countries. Boulder: Westview Press.

Shavit, Yossi, Richard Arum, and Adam Gamoran (eds.). 2007. Stratification in Higher Education: A Comparative Study. Stanford: Stanford University Press.

Smits, Jeroen, Wout Ultee, and Jan Lammers. 1998. Educational Homogamy in 65 Countries: An Explanation of Differences in Openness Using Country-Level Explanatory Variables. American Sociological Review 63(2): 264-285.

Treiman, Donald. 1970. Industrialization and Social Stratification. Sociological Inquiry 40(2): 207-234.

Van Bavel, Jan. 2012. The Reversal of Gender Inequality in Education, Union Formation and Fertility in Europe. Vienna Yearbook of Population Research 10: 127-154.

Vermunt, Jeroen K. 1997. LEM 1.0: A General Program for the Analysis of Categorical Data. Tillburg: Tillburg University.

Vincent-Lancrin, Stéphan. 2008. The Reversal of Gender Inequalities in Higher Education. Pp. 265-298 in Higher Education to 2030, Volume 1, Demography, edited by OECD. Paris: OECD Publishing.

Weber, Max. 1978. Economy and Society. Berkeley: University of California Press.

Widmer, Eric. 2010. Family Configurations. A Structural Approach to Family Diversity. London: Ashgate Publishing.

Widmer, Eric, Manuela Schicka, Michèle Ernst Stähli, Jean-Marie Le Goff, and René Levy. 2012. "If I Had Known Our Couple Turned That Way, I Would Not Have Stopped Working”: A Biographical Account of Labour Force Participation and Conjugal Love. Sociologia e Politiche Sociali 15(2): 29-49.

Xie, Yu. 1992. The Log-Multiplicative Layer Effect Model for Comparing Mobility Tables. American Sociological Review 57(3): 380-395. 


\section{$7 \quad$ Appendix}

Appendix $1 \quad$ Construction of cohorts according to age intervals

\begin{tabular}{c|c|c|c|c}
\hline $\begin{array}{c}\text { Cohort } \\
\text { (age) }\end{array}$ & $\begin{array}{c}32 \\
(30-34)\end{array}$ & $\begin{array}{c}37 \\
(35-39)\end{array}$ & $\begin{array}{c}42 \\
(40-44)\end{array}$ & $\begin{array}{c}47 \\
(45-49)\end{array}$ \\
\hline $\begin{array}{c}1952-1956 \\
(1950-1958)\end{array}$ & & & & $X$ \\
\hline $\begin{array}{c}1957-1961 \\
(1955-1963)\end{array}$ & & $x$ & $X$ & $X$ \\
\hline $\begin{array}{c}1962-1966 \\
(1960-1968)\end{array}$ & & $X$ & $X$ & \\
\hline $\begin{array}{c}1967-1971 \\
(1965-1973)\end{array}$ & $X$ & $X$ & & \\
\hline $\begin{array}{c}1972-1976 \\
(1970-1978)\end{array}$ & $X$ & & & \\
\hline $\begin{array}{c}1977-1981 \\
(1975-1983)\end{array}$ & $X$ & & & \\
\hline
\end{tabular}

Appendix 2 Cross-tabulation of couples' employment status and couple arrangements variable

\begin{tabular}{l|c|c|c}
\hline & Woman full-time work & Woman part-time work & Woman no job \\
\hline Man full-time work & symmetrical & partly asymmetrical & fully asymmetrical \\
Man part-time work & partly asymmetrical & symmetrical & partly asymmetrical \\
Man no job & fully asymmetrical & partly asymmetrical & symmetrical \\
\hline
\end{tabular}




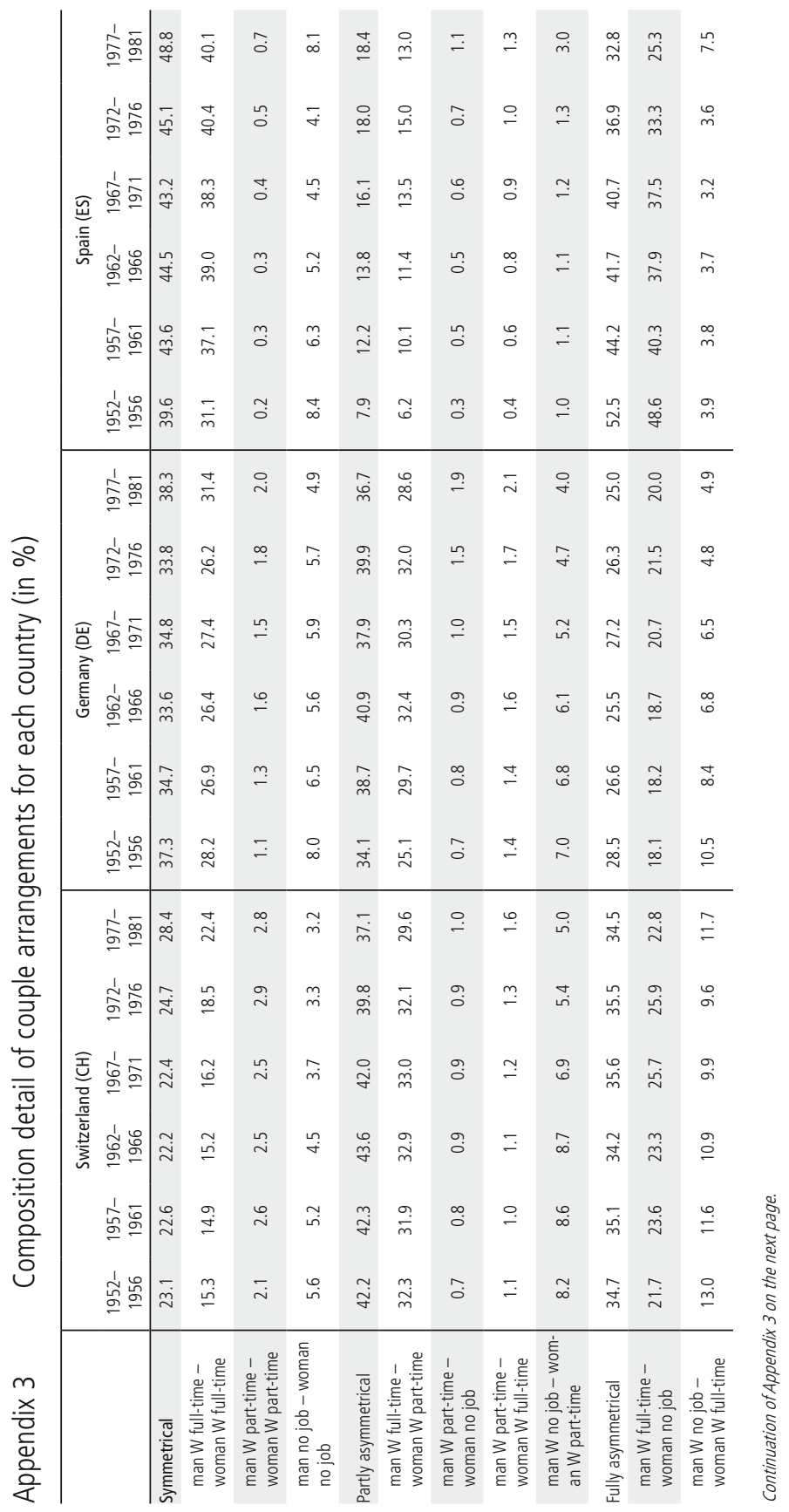




\begin{tabular}{|c|c|c|c|c|c|c|c|c|c|c|c|c|}
\hline 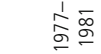 & 帒 & ه్లి & $\stackrel{m}{-}$ & $\stackrel{+}{i}$ & $\frac{n}{m}$ & 芦 & $\bar{i}$ & $\stackrel{\infty}{\longrightarrow}$ & $\stackrel{\sim}{\sim}$ & $\underset{\sim}{\stackrel{n}{\sim}}$ & $\stackrel{\substack{n \\
\infty}}{\stackrel{\infty}{\infty}}$ & $\stackrel{\infty}{m}$ \\
\hline & $\hat{\check{J}}$ & $\begin{array}{l}\text { o } \\
\text { di }\end{array}$ & $\equiv$ & F & $\underset{m}{m}$ & i̊ & 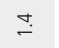 & $\stackrel{\circ}{\longrightarrow}$ & $\cong$ & 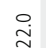 & $\stackrel{\leftrightarrow}{g}$ & $\stackrel{\llcorner}{\sim}$ \\
\hline 美高客 & 苧 & $\stackrel{g}{\dot{p}}$ & $\stackrel{\circ}{-}$ & $\stackrel{\circ}{+}$ & $\bar{m}$ & $\stackrel{\sigma}{m}$ & $\stackrel{\simeq}{\simeq}$ & $\stackrel{m}{=}$ & $\cong$ & $\stackrel{m}{\sim}$ & 요 & $\stackrel{n}{\sim}$ \\
\hline 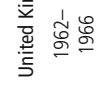 & dे & 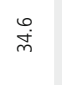 & 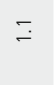 & F & mo & $\overline{\dot{m}}$ & '̊ㅇㅇ & $\stackrel{\stackrel{n}{\longrightarrow}}{=}$ & $\stackrel{\infty}{-}$ & ฮี & 苂 & $\stackrel{\leftrightarrow}{\sim}$ \\
\hline $\begin{array}{l}1 \\
\vdots \\
\varrho\end{array}$ & $\begin{array}{l}\mathscr{q} \\
\dot{q}\end{array}$ & $\underset{\stackrel{n}{m}}{\stackrel{n}{m}}$ & $=$ & $\stackrel{m}{n}$ & $\stackrel{m}{m}$ & $\bar{m}$ & $\stackrel{\infty}{\circ}$ & $\stackrel{\stackrel{n}{=}}{-}$ & $\stackrel{?}{?}$ & $\begin{array}{l}\infty \\
\stackrel{\infty}{0}\end{array}$ & $\stackrel{\infty}{\stackrel{\infty}{m}}$ & $\stackrel{\circ}{m}$ \\
\hline 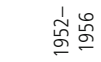 & 字 & $\underset{m}{\stackrel{g}{m}}$ & $\stackrel{m}{=}$ & นُ & $\underset{m}{\stackrel{\leftrightarrow}{m}}$ & $\underset{m}{\stackrel{j}{m}}$ & $\stackrel{\infty}{\circ}$ & $\stackrel{n}{\longrightarrow}$ & $\stackrel{\infty}{\sim}$ & $\underset{g}{g}$ & $\bar{m}$ & $\stackrel{\infty}{m^{\prime}}$ \\
\hline$\stackrel{\bar{\alpha}}{\stackrel{్}{\sigma}}$ & $\stackrel{\infty}{\infty}$ & $\underset{\infty}{\infty}$ & $\stackrel{\text { }}{\infty}$ & $\stackrel{m}{\sim}$ & $\underset{\infty}{m}$ & $\begin{array}{l}\infty \\
\stackrel{g}{g}\end{array}$ & $\stackrel{\infty}{-}$ & $\bar{m}$ & $\stackrel{\stackrel{n}{m}}{m}$ & $\hat{m}$ & $\stackrel{m}{=}$ & $\stackrel{m}{\sim}$ \\
\hline & $\underset{\sim}{\sim}$ & $\bar{\Xi}$ & $\stackrel{n}{n}$ & $\stackrel{\infty}{-}$ & mó & 守 & $\stackrel{m}{=}$ & $\bar{i}$ & $\stackrel{i}{i}$ & 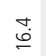 & ีㅗ & $\stackrel{\simeq}{\simeq}$ \\
\hline $\begin{array}{l}z \\
y \\
c\end{array}$ & $\stackrel{+}{\circ}$ & $\stackrel{n}{\sigma}$ & $\bar{\infty}$ & 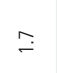 & $\frac{n}{6}$ & $\overline{\dot{b}}$ & 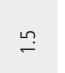 & $\stackrel{\circ}{i}$ & $\stackrel{\circ}{i}$ & $\bar{g}$ & $\stackrel{9}{=}$ & $\stackrel{\simeq}{\simeq}$ \\
\hline 咅 & $\stackrel{\infty}{=}$ & $\bar{\infty}$ & $\stackrel{\infty}{\sim}$ & $\stackrel{9}{?}$ & ఫิ & 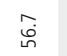 & $\stackrel{n}{=}$ & $\stackrel{9}{?}$ & $\bar{i}$ & $\stackrel{m}{\sigma}$ & $\begin{array}{l}\circ \\
\stackrel{\infty}{0}\end{array}$ & $\stackrel{m}{-}$ \\
\hline & $\begin{array}{l}\stackrel{n}{\infty} \\
\infty \\
\infty\end{array}$ & $\stackrel{\circ}{r}$ & $\bar{\infty}$ & $\stackrel{\infty}{\sim}$ & $\frac{9}{6}$ & $\begin{array}{l}\infty \\
\stackrel{1}{\circ}\end{array}$ & $\stackrel{\infty}{-}$ & $\stackrel{?}{?}$ & $\stackrel{\stackrel{n}{m}}{m}$ & $\begin{array}{l}\stackrel{\circ}{\circ} \\
\stackrel{0}{*}\end{array}$ & $\stackrel{\infty}{\infty}$ & $\stackrel{\stackrel{n}{2}}{=}$ \\
\hline & $\begin{array}{l}\stackrel{n}{\infty} \\
\infty \\
\infty\end{array}$ & $\stackrel{\sim}{\infty}$ & $\hat{\sigma}$ & $\stackrel{\leftrightarrow}{m}$ & $\stackrel{m}{n}$ & 움 & i் & $\stackrel{n}{=}$ & $\stackrel{\dot{m}}{\dot{m}}$ & $\stackrel{\sim}{\sim}$ & $\bar{\beth}$ & $\stackrel{ \pm}{\leftrightarrows}$ \\
\hline & ì & $\begin{array}{l}\dot{\varphi} \\
\dot{\gamma}\end{array}$ & $\stackrel{\circ}{-}$ & $\underset{+}{+}$ & $\stackrel{\vartheta}{\sim}$ & ஓे & $\stackrel{m}{-}$ & $\stackrel{\circ}{-}$ & $\stackrel{\circ}{-}$ & $\stackrel{\circ}{\stackrel{\sim}{\sim}}$ & $\stackrel{\infty}{\stackrel{i}{\sim}}$ & $\stackrel{\infty}{m}$ \\
\hline & $\bar{\delta}$ & 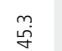 & 웅 & $\stackrel{\rho}{r}$ & ్ֶలి & $\underset{\sim}{\sim}$ & 영 & $\stackrel{\stackrel{n}{\longrightarrow}}{=}$ & $\stackrel{0}{-}$ & $\underset{\sim}{\sim}$ & $\stackrel{m}{i}$ & $\stackrel{m}{m}$ \\
\hline 주 & वं & $\stackrel{\stackrel{n}{f}}{f}$ & $\stackrel{\circ}{-}$ & $\stackrel{\infty}{m}$ & ㅇ. & $\stackrel{g}{d}$ & ô. & $\stackrel{\text { ำ }}{-}$ & $\stackrel{\infty}{-}$ & 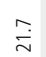 & $\stackrel{\sim}{\infty}$ & $\stackrel{+}{m}$ \\
\hline 焉 & gे & 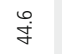 & $=$ & $\mathcal{F}$ & $\stackrel{\infty}{\stackrel{\infty}{\sim}}$ & $\stackrel{m}{\sim}$ & ó. & $\stackrel{\stackrel{n}{\prime}}{=}$ & $\stackrel{n}{\sim}$ & $\stackrel{m}{\sim}$ & $\stackrel{\infty}{\underline{0}}$ & $\stackrel{+}{+}$ \\
\hline & m. & $\begin{array}{l}0 \\
\dot{J}\end{array}$ & g. & F & $\stackrel{\stackrel{\check{J}}{\sim}}{ }$ & 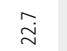 & $\stackrel{\circ}{\circ}$ & $\stackrel{m}{=}$ & $\stackrel{n}{\sim}$ & 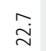 & $\stackrel{\simeq}{\simeq}$ & نํ. \\
\hline 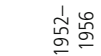 & $\begin{array}{l}\infty \\
\dot{g} \\
\dot{q}\end{array}$ & $\stackrel{\circ}{\ddot{\gamma}}$ & $\hat{o}$ & $\overline{6}$ & $\bar{d}$ & : & $\hat{o}$ & $\stackrel{\simeq}{=}$ & $\stackrel{n}{\sim}$ & $\overline{i j}$ & $\stackrel{m}{\sim}$ & $\stackrel{\infty}{+}$ \\
\hline & 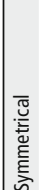 & 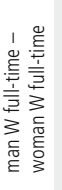 & 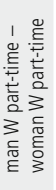 & 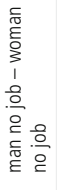 & 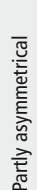 & 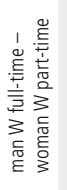 & 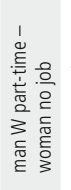 & 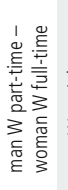 & 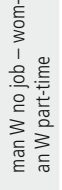 & 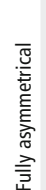 & 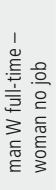 & 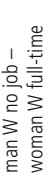 \\
\hline
\end{tabular}


Appendix $4 \quad$ Trends in educational expansion

Upper secondary education or below

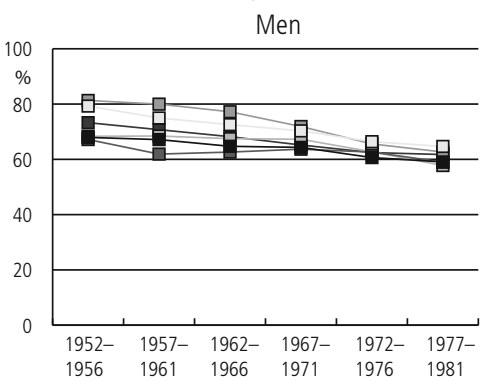

Women

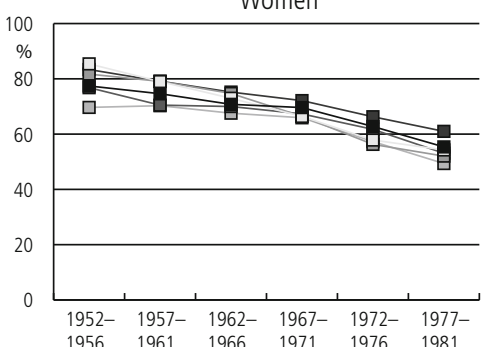

Post-secondary/tertiary education

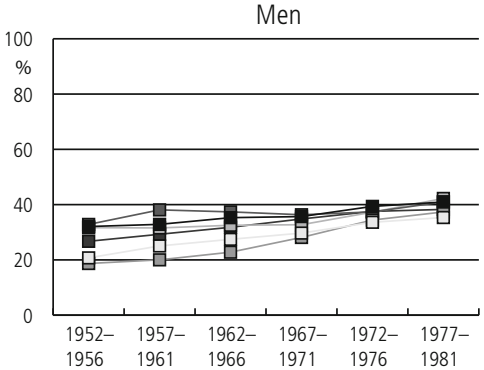

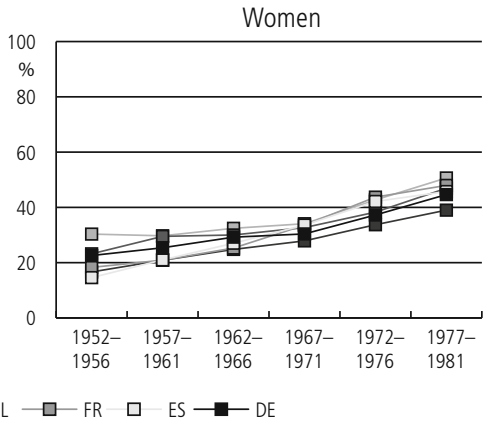

Appendix $5 \quad$ Homogamy trends across cohorts

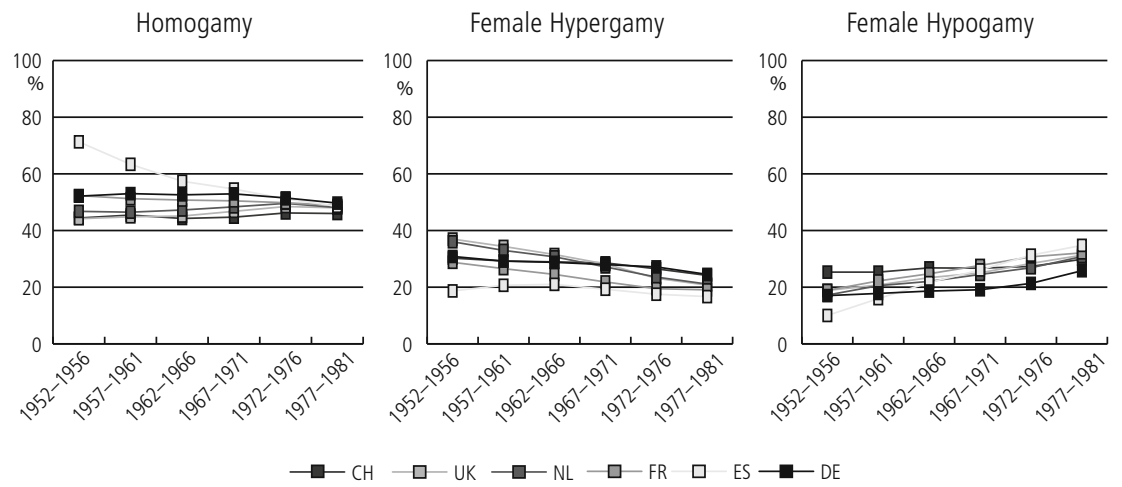




\section{Seismo}

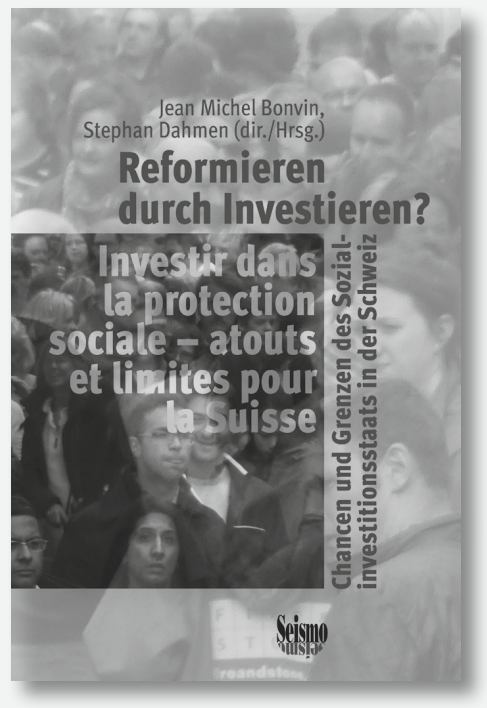

L'Etat d'investissement social se présente comme une stratégie de réforme de l'Etat social en vue de répondre aux nombreuses critiques auxquelles il est actuellement soumis. La conversion des États sociaux européens à l'investissement social vise ainsi à restaurer leur légitimité et à relever les défis démographiques et économiques posés aux États sociaux contemporains. Suivant les partisans de cette conception, la réorientation des dépenses sociales vers l'investissement dans la formation et le développement du capital humain notamment en facilitant l'accès à l'emploi, en accroissant les investissements dans les enfants et en privilégiant une nouvelle conception de la politique sociale comme facteur productif - permettra de réduire les inégalités sociales et de contribuer à la viabilité des États sociaux contemporains. Cet ouvrage examine la forme prise par l'investissement social en Suisse et les effets qui en résultent. II discute de manière analytique et critique les fondements idéologiques et les implications pratiques de la stratégie de l'investissement social.

Jean-Michel Bonvin est professeur ordinaire de sociologie et de socioéconomie à l'Université de Genève, Stephan Dahmen est chargé d'enseignement et doctorant à la Faculté des Sciences de l'éducation de l'Université de Bielefeld. www.seismoverlag.ch/info@seismoverlag.ch www.editions-seismo.ch/info@editions-seismo.ch

\section{Jean Michel Bonvin}

Stephan Dahmen (dir./Hrsg.)

\section{Reformieren durch Investieren?}

Chancen und Grenzen des

Sozialinvestitionsstaats in

\section{der Schweiz}

\section{Investir dans la protection sociale - atouts et limites pour} la Suisse

Mit Beiträgen in deutscher und französischer Sprache. Avec des contributions en allemand et en français.

144 Seiten/pages, SFr. 28.-

Als Antwort auf den zunehmenden Druck, mit dem sich der Sozialstaat konfrontiert sieht, hat sich das Konzept sozialer Investitionen als Reformstrategie entwickelt. Der sozialinvestive Umbau europäischer Wohlfahrtsstaaten verspricht sowohl Antworten auf drängende Legitimationsfragen als auch auf gegenwärtige demografische und ökonomische Herausforderungen des Wohlfahrtstaates zu liefern. Die Neuausrichtung der Ausgaben des Sozialstaates auf Investitionen in Humankapital, etwa durch die Verbesserung des Zugangs zu Beschäftigung, den Ausbau der Investitionen in Kinder und eine konsequente Neubestimmung von Sozialpolitik als Produktivfaktor ermögliche es sowohl bestehende soziale Ungleichheiten zu reduzieren als auch die Nachhaltigkeit moderner Wohlfahrtstaaten zu gewährleisten. Welche Ausprägungen hat das Sozialinvestitionsparadigma in der Schweiz angenommen und welche Auswirkungen ergeben sich aus dem sozialinvestiven Umbau des Sozialstaates? Das Buch liefert eine kritische Analyse und diskutiert die ideologischen Grundlagen und praktischen Implikationen sozialer Investitionen.

Jean Michel Bonvin ist Professor an der Fachhochschule Westschweiz (éésp) Waadt und Lehrbeauftragter an der Universität Genf. Stephan Dahmen ist Lehrbeauftragter und Doktorand in Erziehungswissenschaften an der Universität Bielefeld. 